\title{
Opportunistic Election Timing, a Complement or Substitute for Economic Manipulation?
}

Tristin Beckman, University of Oxford

Petra Schleiter, University of Oxford

Parliamentary governments often use their powers opportunistically to enhance their reelection chances. Yet, how they combine the two most commonly available strategies - economic manipulation prior to elections and opportunistic election timing - remains poorly understood. Do incumbents employ these powers jointly, or does the power to time elections temper incentives to engage in distortive economic manipulation? Previous research gives contradictory answers to these questions. We advance the debate by presenting the first cross-national comparative analysis of the effects of opportunistic election timing on economic manipulation, drawing on data from 20 developed parliamentary democracies. Our results demonstrate a powerful substitution effect: when leaders can time elections, they are significantly less likely to manipulate the economy. This finding not only clarifies the theoretical debate, it also has practical implications for political reforms that aim to prevent incumbents from distorting elections in their favor.

$\mathrm{P}$ oliticians are acutely aware that voters reward or punish governments for their record in office (Fiorina 1981; Key 1966; Powell 2000), in particular the state of the economy (Barreiro 2008). With that in mind, reelection-seeking incumbents often use their powers opportunistically to feign performance and competence. Two strategies are particularly well documented: the practice of timing elections to coincide with positive economic conditions, a strategy that is also referred to as "political surfing" (Chowdhury 1993; Heckelman and Berument 1998; Ito and Park 1988; Smith 2004; Voia and Ferris 2013) and the manipulation of the economy to improve voter welfare prior to elections (Canes-Wrone and Park 2012; Hallerberg, Vinhas de Souza, and Clark 2002; Nordhaus 1975; Shi and Svensson 2006; Tufte 1978). Both strategies have been shown to improve the reelection chances of incumbents (Aidt, Veiga, and Veiga 2011; Roy and Alcantara 2012; Schleiter and Tavits 2016).

Normatively, there may be cause for concern about each of these strategies: economic manipulation not only has the undesirable effect of distorting the economy and enhancing, rather than smoothing, economic cycles, but both strategies can also contradict the spirit of democracy and reduce political accountability. They distort electoral contests in favor of incumbents by enabling governments to make themselves appear more competent than they in fact are. If these incumbents turn out, postelection, to be less capable than they had previously seemed (Smith 2004), these strategies have negative consequences for economic performance and voter welfare. ${ }^{1}$

Despite the importance and prevalence of these reelectionenhancing tools, however, we know surprisingly little about

Tristin Beckman (tristinbeckman@gmail.com) is a postdoctoral research fellow in political economy and experimental research at the University of Oxford in the Department of Politics and International Relations, Oxford OX1 3UQ. Petra Schleiter (petra.schleiter@politics.ox.ac.uk) is a professor of comparative politics at the University of Oxford in the Department of Politics and International Relations, Oxford OX1 3UQ.

Data and supporting materials necessary to reproduce the numerical results in the article are available in the JOP Dataverse (https://dataverse.harvard.edu /dataverse/jop). An online appendix with supplementary material is available at https://doi.org/10.1086/707794. Petra Schleiter gratefully acknowledges the financial support for this research, which was provided by the Oxford University Press John Fell Fund (grant reference number 153/103).

1. The literature on political-economic cycles overwhelming concludes that economic manipulation has welfare-reducing effects because it distorts the economy and accentuates moral hazard problems for voters by making incumbents appear more competent than they actually are (Nordhaus 1975; see Shi and Svensson [2003] for a review). The view that the creation of economic cycles is undesirable receives further support in the literature on smoothing taxation and consumption and on the role of governments in cushioning economic shocks (Asdrubali, Sørensen, and Yosha 1996; Hepp and von Hagen 2012). Note, however, the partially dissenting view of Rogoff (1990). Rogoff (1990) recognizes the economic distortions caused by manipulation but suggests that manipulation may have benefits in signaling incumbent competence to voters because the marginal cost of manipulating the economy is lower for competent (compared to incompetent) incumbents, who therefore manipulate more.

The Journal of Politics, volume 82, number 3. Published online May 13, 2020. https://doi.org/10.1086/707794 (C) 2020 by the Southern Political Science Association. All rights reserved. 0022-3816/2020/8203-0021\$10.00 
how governments in developed parliamentary democracies, to whom both options are available, use them. Do they employ both strategies jointly to maximize their chances of reelection? Does the power to time elections to favorable circumstances temper incentives to engage in distortive economic manipulation prior to elections?

Previous research gives contradictory answers to these questions. One theoretical perspective anticipates that governments complement economic manipulation with election timing to improve their chances of reelection (Chappell and Peel 1979; Lächler 1982). ${ }^{2}$ The contrasting approach expects politicians to substitute opportunistic election timing for costly and distortionary attempts to manipulate the economy (Franzese and Jusko 2006; Kayser 2005). To date, empirical work has failed to resolve this debate. Singlecountry studies yield mixed results (Cargill and Hutchinson 1991; Chowdhury 1993; Ito and Park 1988). Systematic comparative studies of political business cycles in developed democracies do not directly address the question whether incumbents substitute or complement economic manipulation with opportunistic election timing, but focus instead on the question whether cycles exist at all (Alesina, Cohen, and Roubini 1993; Brender and Drazen 2005; Katsimi and Sarantides 2012; Schneider 2010; Shi and Svensson 2006). ${ }^{3}$ In sum, a generalizable answer to the question whether incumbents employ opportunistic election timing to complement economic manipulation or as a substitute has yet to be provided. $^{4}$

Advancing this debate is crucial not only to a better understanding of electoral politics in parliamentary democracies but also to the deliberations about reforms that aim to improve accountability by restricting these opportunistic strategies. Our study addresses this task. We show that the debate is rooted in two divergent theoretical conceptions of

2. Throughout this paper, we use the term "complement" in the linguistic sense of contributing an additional benefit rather than in the economic sense of complements as goods that experience joint demand. Hence, we describe election timing as a complement to manipulation to indicate its use in addition to economic manipulation, rather than as a strategy for which demand increases in economic manipulation.

3. The primary goal of this work is to examine whether politicaleconomic cycles exist in developed democracies. These studies often control for early elections or distinguish between electoral manipulation prior to regular and early elections, which, as we discuss below, does not account for the endogeneity between the two opportunistic strategies.

4. An extensive literature examines whether opportunistic elections give rise to incumbency advantages (Grofman and Van Roozendaal 1994; Powell and Whitten 1993; Roy and Alcantara 2012; Schleiter and Tavits 2016; Smith 2004). However, this body of work does not explore the relationship between strategic election calling and economic manipulation. the benefits of opportunistic election timing to incumbents. To evaluate the competing arguments empirically, we construct an original data set of economic manipulation in 20 developed parliamentary democracies from 1997 to 2015. We focus on incumbents' choices to manipulate the economy by diverting public spending from long-term investment to short-term consumption, which is a policy tool available to governments even in high-transparency developed democracies where the opportunistic use of other fiscal and monetary policy instruments is often constrained. To identify the effect of opportunistic election timing on economic manipulation, we contrast how government spending priorities change over the parliamentary term when incumbents have extensive - as opposed to little - influence on election timing. Our results reveal a powerful substitution effect. Leaders who have the power to time elections are less likely to manipulate the economy by shifting public spending from investment to consumption to boost voter welfare prior to elections.

This finding contributes to several literatures in comparative politics and has important practical implications. First, it advances the unresolved theoretical debate in the literature on political-economic cycles about the linkage between economic manipulation and opportunistic election timing and simultaneously contributes to a better understanding of why economic policy cycles in developed parliamentary democracies have proven so elusive in empirical work. Second, our finding adds to the literature on comparative political institutions by providing the first systematic cross-national evidence of the consequences of assembly dissolution powers for economic policy. Finally, our work has practical implications for current political reform debates in the United Kingdom, Ireland, Australia, New Zealand, and Canada about fixed electoral terms as a means to prevent incumbents from distorting electoral contests in their own favor. ${ }^{5}$ It highlights that attempts to limit opportunistic election timing give governments incentives to compensate for their lost advantage by increasing the use of economic manipulation. Hence efforts to reduce incumbent discretion to schedule early elections require consideration of the relative welfare implications of both strategies to society and of ways to mitigate their potential costs.

\footnotetext{
5. "House of Commons Library Research Papers: Fixed-Term Parliaments," SN/PC/831, 2007, United Kingdom; https://www.citizensassembly .ie/en/Meetings/Meeting-of-the-Assembly-on-Fixed-term-parliaments.html, April 2018 (Ireland); New Zealand Parliamentary Service 2013. Also see Roy and Alcantara (2012).
} 


\section{STRATEGIC ELECTION TIMING AND ECONOMIC MANIPULATION}

An extensive literature shows that voters are performance oriented (Fiorina 1981; Key 1966; Powell 2000) and that governments are consistently more successful electorally when economic performance is strong rather than weak (Barreiro 2008; Duch and Stevenson 2008; Lewis-Beck and Stegmaier 2000; Nannestad and Paldam 1994). The electorate, this work suggests, prefers capable and high-performing incumbents to incompetent ones. However, because government competence cannot be observed directly, voters infer it from recent performance, in particular, economic conditions. This process is characterized by information asymmetries (see Healy and Malhotra [2013] for a recent review). Economic conditions may or may not accurately reflect government competence, and incumbents have significant information advantages compared to voters in assessing the effect of their policy choices and their ability to deliver future economic performance.

According to the literatures on political-economic cycles and political surfing, these information asymmetries enable self-interested incumbents to employ opportunistic strategies for electoral gain. That is, economic manipulation and political surfing may allow incumbents to create the appearance of government competence by ensuring that elections coincide with favorable economic circumstances. Economic manipulation exploits imperfect information among voters by shifting economic resources from the future to the preelection present, which imposes a hidden, distortionary tax on the economy after the election (Nordhaus 1975; Rogoff 1990; Rogoff and Sibert 1988). Voters observe and reward welfare improvements prior to the election while the adverse impact of the distortionary intervention only becomes evident postelection. ${ }^{6}$ The literature on political surfing suggests that election timing may similarly enable governments to exploit private information about the source of the economy's performance and its likely future trajectory by scheduling elections during exogenously triggered economic upturns. Voters observe improved economic conditions prior to elections,

6. The literature on economic manipulation intersects with extensive debates about voter rationality and the time horizons that voters apply in assessing incumbents (see Hibbs [2006] and Healy and Malhotra [2013] for reviews). Empirical findings suggest three conclusions: first, voters' evaluations of their government most often follow a coherent logic. Second, voters base their judgments of incumbents more on retrospective performance than on prospective expectations, and, third, voters attribute greater importance to recent performance than to the more distant past. As a result voters can be expected to focus on preelection performance and to discount previously observed effects of opportunistic interventions. while the reduction in performance following the exogenously generated upturn manifests only after the election date (Ito and Park 1988; Kayser 2005).

When incumbents seek to improve their chances of reelection, they can be expected to "use all policy tools, in proportion to their effectiveness in satisfying their electoral goals" (Franzese and Jusko 2006, 550). As noted above, governments in most parliamentary democracies have some influence on election timing - in addition to their ability to manipulate the economy - although the scope of their discretion to trigger early elections varies extensively (Goplerud and Schleiter 2016; Strøm and Swindle 2002). Whether they can be expected to employ these powers to complement or substitute for economic manipulation, however, remains the subject of debate because extant work has produced two divergent accounts of the benefits of opportunistic election timing to incumbents in satisfying their electoral goals.

The original political business cycle literature sees the benefits of election timing and economic manipulation as distinct-while economic manipulation allows incumbents to feign competence, timing enables them to call an election when economic performance peaks. The literature on opportunistic election timing, by contrast, views the two strategies' benefits as identical-because incumbents can feign competence by manipulating the economy or timing the election to exogenous shocks, politicians prefer political surfing, which does not cause economic distortions. To date this debate remains unresolved. As we shall see, election timing can plausibly be expected to complement or substitute for economic manipulation under divergent but equally well supported assumptions regarding voter behavior. This makes the evaluation of the two competing perspectives ultimately an empirical question.

\section{Election timing is used to complement economic manipulation}

Models of political-economic cycles originally assumed fixed electoral terms, during which incumbents use macroeconomic, that is, monetary (Nordhaus 1975) or fiscal (Drazen 2001) policy tools, to boost their reelection chances by improving voter welfare prior to elections. Scholars soon adapted these models to a more realistic institutional setting by accounting for the ability of governments in most parliamentary democracies to influence the timing of elections. These studies expect incumbents to complement economic manipulation with election timing. For instance, Chappell and Peel (1979) propose that politicians combine both strategies by choosing the election date to reflect their target in improving voter welfare (in this model, reducing unemployment) and the speed with which the economy 
responds. According to this extension of the Nordhaus model, incumbents generally manipulate the economy and then time elections when economic performance peaks. Hence, less demanding economic challenges and a faster economic response to manipulation produce earlier elections while greater challenges and a more sluggish economic response yield a later election date. Lächler $(1982,113)$ extends this argument by proposing that governments will, over time, converge on a steady cycle of early elections combined with economic manipulation that maximizes their chances of securing reelection. In these models, the option of timing elections discretionarily does not temper the resort to economic manipulation.

The assumption shared by these models is that economic manipulation and election timing have distinct benefits for incumbents, who, given their competence alone, would struggle to secure reelection. While economic manipulation increases voter welfare in the short term and gives the illusion of government competence, election timing enables politicians to manage the practical difficulties of manipulating the economy for electoral gain by scheduling elections at the precise time when voter welfare peaks.

There are good reasons to expect that both types of strategic advantage are valuable to incumbents. In many developed democracies, the incumbent government's capacity to engage in economic policy manipulation is limited by factors such as currency union (i.e., the euro) or exchange rate regimes, the need to coordinate with often independent central banks (Cusack 2001), exposure to international markets (Clark 2003; Franzese 2003), fiscal solvency considerations (Blais, Blake, and Dion 1993), and fiscal monitoring and transparency rules (Alt and Lassen 2006). As a result, the interventions open to incumbents may not all be easily targetable and timeable. Moreover, the effect of any given intervention on the incumbent's electoral support is inherently uncertain and difficult to predict with accuracy (Franzese and Jusko 2006, 549). Decisions to manipulate the economy, then, are error prone, because they are based on the incumbent's best guesses rather than certainty about the impact of any chosen manipulation on electoral support for the government. While strategic election timing cannot improve voter welfare, it moderates the practical difficulty of accurately timing the welfare improvements produced by economic manipulation because it enables incumbents to call an election when voter welfare peaks. According to this argument, governments can generally be expected to manipulate the economy and to supplement that strategy with election timing, when that option is available to them. Hence, political business cycles should be equally evident in institutional contexts with and without discretionary election timing.

\section{Election timing is used to substitute for economic manipulation}

The contrasting argument that politicians substitute election timing for economic manipulation sees the benefits for politicians of the two strategies as identical (Kayser 2005). Building on the literature on opportunistic election timing, this perspective suggests that both strategies enable incumbents to feign competence by ensuring that elections occur in the context of increased voter welfare. Political surfing creates the illusion of incumbent competence through opportune timing of the election to favorable exogenous shocks, ${ }^{7}$ economic manipulation through a hidden and distortionary tax on the future (Kayser 2005, 21).

This account also draws attention to the asymmetric economic costs of the two strategies. By shifting economic resources from the future to the present to signal competence to voters, incumbents create economic dislocations that impose a tax on the postelection future. After the election, these distortions must be remedied, which reduces economic performance. This postelection cost may temper politicians' incentives to manipulate the economy (Kayser 2005, 23). Political surfing, in contrast, allows incumbents to feign competence by scheduling elections to exogenously induced positive welfare shocks. This reduces the need for economic manipulation and enables governments to boost their reelection chances with no future economic cost.

Given the identical benefits and asymmetric economic costs of the two strategies, incumbents can be expected to substitute political surfing for manipulation when that option is open to them. Hence, constitutional rules, which enable governments to time elections opportunistically, should reduce economic manipulation for electoral gain (Kayser 2005, 25; see also Franzese and Long Jusko 2006, 549).

\section{VOTER REACTIONS AND THE BENEFITS OF POLITICAL SURFING: CONTRADICTORY THEORY AND EVIDENCE}

At the heart of the debate as to whether election timing complements or substitutes for economic manipulation lies

7. Note that strategic election timing may not only have positive but also have negative competence signaling effects. According to Smith (2004), for instance, an unanticipated opportunistic election can signal an impending decline in economic performance and reduce voter support for the incumbent. A recent experimental study tests this proposition and finds that political surfing can, indeed, give rise to concerns about incumbent competence but shows that these concerns do not overwhelm the average voter's support for an incumbent in the context of a wellperforming economy (Schleiter and Tavits 2018). These findings suggest that, on average, the positive competence signal of an election timed to favorable circumstances outweighs the negative signaling effects. 
a disagreement about the benefits of political surfing to incumbents, in particular, whether election timing to exogenous positive economic shocks can be used to feign competence. Central to this debate are contrasting assumptions regarding voter reactions to the strategy. Extant work on electoral behavior offers no guide in resolving this debate because it supports two equally plausible but contradictory conclusions. ${ }^{8}$

According to models of opportunistic election timing, political surfing can be used by governments to signal competence to the electorate because voters do not distinguish between exogenously generated positive welfare shocks, which are beyond the control of incumbents, and local economic performance for which the government is responsible (Kayser 2005, 18). Asymmetric information leads to a misattribution of responsibility by voters, which benefits incumbents. As a result, incumbents are able to substitute political surfing for economic manipulation. The assumption underlying this argument, that is, that imperfectly informed voters may reward (or, indeed, punish) governments for exogenous shocks, finds support in multiple studies of electoral behavior. In subnational and second-order elections, for instance, voters often hold politicians accountable for outcomes that are beyond their jurisdiction (Gelineau and Remmer 2006; Hansen 1999). There is also evidence that politicians may find themselves held to account for random events beyond their control such as poor harvests, droughts, shark attacks, and the vicissitudes of the oil price (Achen and Bartels 2016; Wolfers 2007).

If voter behavior is slightly more informed, however, it is less clear that politicians can signal competence by engaging in political surfing and substitute this strategy for economic manipulation. Several studies suggest that voters distinguish between exogenous welfare shocks, such as those caused by international economic trends, and government-generated economic performance (Kayser and Peress 2012; Powell and Whitten 1993). This work finds that the electorate assesses government performance in light of the broader international economic climate, a result that is particularly plausible in developed democracies, where the media routinely "pre-

8. Unlike work on election timing, the literature on economic manipulation has generated a widely accepted moral hazard model of manipulation, which suggests that incumbents can benefit electorally from manipulation because they have a temporary information advantage (see Shi and Svensson [2003] for a review): whether preelection welfare improvements are due to improved economic performance or manipulation remains unobservable to voters and the media until after the election. Note that the effect of international benchmarking on opportunities to surf, which we discuss in this section, does not impinge on the information asymmetries that underpin economic manipulation. benchmark" government performance by placing it in international context (Kayser and Peress 2012, 379-80). If voters hold incumbents accountable for the over- or underperformance of the domestic economy compared to international trends (Kayser and Peress 2012), political surfing may not allow governments to take credit for exogenous welfare shocks, so that it cannot be substituted for manipulation as a strategy to feign competence. However, international benchmarking does not enable voters to assess whether domestic economic performance is (or is not) due to the self-interested manipulation of the economy by incumbents. Hence, electorally motivated incumbents can still manipulate economic conditions and time elections opportunistically when the economy outperforms the benchmark. This should give governments incentives to complement their manipulative economic interventions with opportunistic election timing in order to maximize their reelection chances. Thus, extant work supports two equally compelling but contradictory theoretical arguments: according to one view politicians can use political surfing as a substitute for economic manipulation; according to the other, political surfing complements, but cannot be used to substitute for, the benefits of economic manipulation.

The existing empirical evidence fails to settle the debate between these contrasting arguments. Case studies reach contradictory conclusions. For example, Cargill and Hutchinson (1991) find that Japanese governments employ both strategies jointly, complementing economic manipulation with elections timed to periods of real output growth. Heckelman and Berument (1998) partially confirm this finding in a comparative study that uncovers evidence of opportunistic election timing in Japan and the United Kingdom but only traces monetary expansions prior to Japanese elections. However, these findings are contradicted by other work on Japan and India, which suggests that economic manipulation is muted or absent because politicians substitute it with election timing (Chowdhury 1993; Ito 1990; Ito and Park 1988).

Systematic cross-national comparative work has focused on the question of whether political business cycles exist at all and makes only limited contributions in advancing the debate. This literature reveals strikingly inconsistent evidence that politicians in developed democracies manipulate the economy for electoral gain. ${ }^{9}$ While some studies suggest that incumbents engage in preelection manipulation

9. A large number of studies extend their focus to developing and new democracies. There is a consensus in this work that electorally motivated economic cycles are common in such settings (Brender and Drazen 2005; Hallerberg et al. 2002; Shi and Svensson 2006; Vergne 2009). 
(Efthyvoulou 2012; Katsimi and Sarantides 2012), others find no such evidence (Brender and Drazen 2005; Shi and Svensson 2006). Moreover, the hypothesis that these inconsistent findings are, at least in part, attributable to the preponderance of endogenous election timing in developed democracies (Franzese and Jusko 2006; Kayser 2005) remains untested. ${ }^{10}$ Some recent work distinguishes between manipulation preceding regular and early elections and yields contradictory and unexpected findings. While Efthyvoulou (2012) reports manipulation prior to regular but not early elections, Katsimi and Sarantides (2012) find manipulation before regular elections and unexpected deficit cycles prior to early elections. The evidence adduced by the existing empirical work, therefore, remains inconclusive.

In sum, the existing literature gives rise to an unresolved contradiction between two equally compelling arguments regarding the use of opportunistic election timing and economic manipulation:

H1. Incumbents complement preelection economic manipulation with opportunistic election timing so that governments who can time elections manipulate the economy no less than their peers who lack that option.

H2. Incumbents substitute preelection economic manipulation by opportunistic election timing so that governments who can time elections manipulate the economy less than their peers who lack that option.

Ultimately, the test of these competing propositions is their ability to account for the real world choices of incumbents, which is why a systematic, comparative cross-national empirical study is required. In what follows, we provide the first such analysis to advance the debate.

\section{EMPIRICAL CHALLENGES AND STRATEGY}

Testing these hypotheses presents three challenges that remain unaddressed in previous work: First, the existing literature is characterized by a theory-empirics mismatch. The theory outlined above focuses on the strategic choice set available to politicians, that is, how the option of timing

10. Economic-political cycles may be more difficult to document in developed (compared to developing democracies) because institutions are stronger, governments weaker, transparency greater, and the audience costs of manipulation are higher (Alt and Lassen 2006). This has prompted a search for cycles in ever more fine-grained policy instruments, which we discuss below when we turn to the measurement of economic manipulation. elections for partisan advantage affects choices to manipulate the economy. This strategic choice set does not correspond to the distinction between early and regular elections on which studies of economic manipulation have relied (Brender and Drazen 2005; Katsimi and Sarantides 2012; Vergne 2009), because early elections can occur even when incumbents have no power to call them, for instance through a vote of no confidence (Schleiter and Issar, forthcoming; Schleiter and Tavits 2016). Moreover, regular elections not only result from the lack of discretion to time elections but may be strategically chosen by incumbents who have the power to call an early election but fear losing it or who are confident of their ability to secure reelection at the end of their term. Hence an adequate test of the theory requires a variable that identifies the strategic choice set available to incumbents rather than actual election timing.

Second, the empirical evaluation of the hypotheses is complicated by the endogeneity between economic manipulation and opportunistic election timing as reelection-enhancing strategies. Endogeneity arises because both political surfing and economic manipulation are jointly conditioned by unobservable and observable factors such as incumbent competence and popularity. For example, competent governments may have little incentive to make use of either strategy while incompetent governments may seek to use both extensively. Similarly, positive shocks to the incumbent's popularity may allow incompetent governments to surf while refraining from manipulation of the economy.

Identifying the effect of election timing on economic manipulation requires an empirical strategy that addresses the potential influence of such confounders. Surprisingly, this endogeneity, though frequently noted in empirical work on political business cycles (e.g., Heckelman and Berument [1998] provide one of the earliest discussions of the problem), is typically not appropriately addressed in systematic comparative studies. Large sample comparative work either distinguishes between the effect of early and regular elections on economic manipulation or splits the sample between these two election types (Brender and Drazen 2005; Katsimi and Sarantides 2012; Vergne 2009). This approach treats regular elections, which are held at the end of the parliamentary term, as "constitutionally predetermined" and exogenous. Yet, when governments have significant influence on early election calling, an incumbent's decision to complete the full parliamentary term is as much a strategic choice as calling an election early. Put differently, these studies do not address the concern that the same underlying electoral motivations drive incumbents' election timing choices as well as their decision to intervene in the economy for electoral gain. 
Third, an adequate test of the competing hypotheses outlined above requires a context-appropriate measure of economic manipulation. The original Nordhaus (1975) model anticipates that incumbents use monetary policy to manipulate real preelection macroeconomic outcomes (i.e., unemployment), and Drazen (2001) generalizes this argument to fiscal policy, that is, budget balances, deficit spending, and tax cuts. Yet, the ability of politicians to use these policy instruments opportunistically is often severely constrained in developed democracies. In many of the democracies that we study, the European Monetary Union, fixed exchange rate regimes, capital mobility, and central bank independence rule out opportunistic monetary policies (Clark et al. 1998). Similar constraints reduce the opportunities for incumbents to engage in fiscal profligacy for electoral gain. For instance, governments' fiscal policy choices are increasingly restricted by domestic and international institutions such as balanced budget legislation, debt ceilings, independent fiscal watchdogs, and the European Stability and Growth Pact. Fiscal transparency and monitoring are designed to make it costly for governments to raise expenditures, inflate deficits, and deteriorate budget balances, which is why incumbents have been shown to avoid such measures and to choose less detectable forms of fiscal interventions to achieve their political goals instead (Alt, Lassen, and Wehner 2014). Studies of cycles in real macroeconomic outcomes, such as inflation, fiscal balances, and their constitutive elements, have struggled to account for the substantial unobserved heterogeneity arising from these constraints.

We address the first two of these challenges, that is, the theory-empirics mismatch and endogeneity, by making use of the constitutional variation in the power of parliamentary governments to time elections (Goplerud and Schleiter 2016; Strøm and Swindle 2002). On a theoretical level, the constitutional authority to time elections provides a direct measure of the strategic choice set available to incumbents, that is, their option to resort to opportunistic election timing in addition to economic manipulation. This approach enables us to overcome the theoretical mismatch, which besets earlier work, between the incumbent's strategic choice set on the one hand and the actual occurrence of early or regular elections on the other hand.

On an empirical level, the reliance on constitutional assembly dissolution powers enables us to address the concern about the endogeneity between opportunistic election timing and economic manipulation as reelection-enhancing strategies. Unlike actual opportunistic election timing, constitutionally enshrined dissolution powers can be assumed not to vary systematically with an incumbent's popularity and competence, as we explain below. Under this assumption we can test our competing hypotheses (i.e., that economic manipulation prior to elections is - or is not-conditioned by the availability of strategic election timing) by interacting government assembly dissolution powers with the elapsing parliamentary term. This allows us to capture the effect on economic manipulation of including opportunistic election timing in the incumbent's strategic choice set by contrasting the impact of approaching elections on economic manipulation at high and low levels of incumbent dissolution power. When incumbent competence and popularity do not vary systematically with dissolution powers, the difference between the conditional effect of approaching elections on manipulation at the two levels of assembly dissolution power can be estimated without bias (see Frye [2010] and Rajan and Zingales [1998] for a similar approach).

Government competence and popularity is unlikely to be systematically correlated with the level of incumbent assembly dissolution power for two reasons. First, dissolution regimes were typically forged as part of constitutional settlements that resulted from crisis, revolution, regime collapse, defeat in war, or independence (Elster 1995, 371). These situations were characterized by high levels of uncertainty about the effects of institutional rules, which generally prevented parties from choosing institutions that maximized their interests (Andrews and Jackman 2005). Second, most constitutions are entrenched precisely in order to prevent the incumbent government from changing the constitutional framework for its own benefit. Entrenchment ensures that constitutional change requires the support of supermajorities or even cross-temporal coalitions (when intervening elections are required for a constitutional change to take effect). ${ }^{11}$ Thus, high and low levels of governmental assembly dissolution powers can plausibly be conceived as exogenous to an incumbent's underlying popularity and competence. Analyses examining the assumption underpinning this approach are available in the Supplementary Information (SI), sections SI 3.2 and SI 3.3 (Supplementary Information is available online).

To address the third challenge of devising a contextappropriate measure of economic manipulation, we focus on a policy instrument that even incumbents in hightransparency, developed parliamentary democracies can generally manipulate: the composition of public spending, measured as the ratio of public spending on short-term current

11. In our sample only the United Kingdom lacks an entrenched constitution so that changes to the dissolution rules for partisan advantage can feasibly be achieved. However, the only change to the UK dissolution rules since 1945 is the 2011 Fixed-Term Parliaments Act, which in fact removes the prime minister's discretion to call elections. 
expenditures to longer term investment expenditures (see Katsimi and Sarantides [2012] and Vergne [2009] for a similar approach). Shifts in compositional spending do not increase budget deficits, which enables politicians to sidestep fiscal rules and transparency requirements that monitor budget balances. A preelection increase in spending on investments improves voter welfare in the long term (i.e., after the election) but not in the present. Short-term consumption, in contrast, allows politicians to improve voter welfare in the present but has no long-run positive effects. By manipulating compositional spending incumbents can therefore shift resources from the future to the present to improve voter welfare prior to elections. The supplementary analyses in SI 3.1 test this rationale for our choice of dependent variable by employing alternative measures that take no account of prevailing levels of transparency (expenditures and the cyclically adjusted primary budget balance). ${ }^{12}$

\section{Data and dependent variable}

To test our hypotheses, we construct an original data set of government spending choices in 20 Organization for Economic Cooperation and Development (OECD) parliamentary democracies from 1997 to $2015 .{ }^{13}$ Specifically, we focus on compositional spending, that is, the ratio of consumption spending to investment, observed on an annual basis.

We measure consumption using final central government consumption expenditure data. The measure captures government purchases of domestic goods and services but excludes transfers, such as social security, pensions, and welfare, or unemployment benefits. This ensures that crossnational heterogeneity in social spending does not affect our measure (see SI 3.1 for a robustness test that employs a measure of compositional spending including transfers). Investment is measured using gross capital formation and captures the government's acquisition of physical assets, not including land, minus disposals (summary statistics of all variables and information regarding data sources are available in SI 1). Higher values of the consumption to investment ratio denote more consumption relative to investment. Because of its skewed distribution, we take the natural logarithm of this variable.

12. To preview, in none of these models do we find evidence of economic manipulation. These results demonstrate the importance, in studies of fiscal manipulation, of using measures that are sensitive to fiscal transparency and monitoring in the sample under investigation. They also clarify why our findings deviate from those of previous studies, which have used measures that are not context appropriate.

13. This study includes the following countries: Austria, Belgium, Czech Republic, Denmark, Estonia, Finland, France, Germany, Greece, Hungary, Ireland, Italy, Luxembourg, the Netherlands, Portugal, Slovakia, Slovenia, Spain, Sweden, and the United Kingdom.

\section{Independent and control variables}

In order to establish whether incumbents employ preelection economic manipulation and election timing as substitutable or complementary strategies, we examine to what extent manipulation over the electoral cycle is conditional on the scope of an incumbent's assembly dissolution powers. Our independent variables are the elapsing electoral cycle (i.e., the proportion of the parliamentary term that has elapsed), the incumbent's assembly dissolution powers, and the interaction between these two terms.

We measure the elapsed proportion of the electoral cycle in months. To capture our second independent variable, an incumbent's ability to call an early election, we use Goplerud and Schleiter's (2016) index of constitutional dissolution powers. Specifically, we focus on the government's ability to dissolve parliament discretionarily by relying on the power of prime minister, cabinet collectively, or the government's legislative majority to call early elections. These powers are strongly associated with opportunistic election calling (Schleiter and Tavits 2016, 843). The index ranges from 0 (no dissolution powers) to 10 (full discretion to dissolve). Further information about the index (including country scores) is available in SI 2. To examine the conditionality of the electoral cycle's effect on dissolution powers we interact these two variables (Electoral Cycle $\times$ Dissolution Powers).

Our analysis controls for a series of factors that potentially confound the relationship between dissolution powers, the electoral cycle, and manipulation. Specifically, GDP Growth may obviate the need to manipulate the economy in order to improve the incumbent's reelection chances. Hence, growth should be negatively associated with the ratio of consumption to investment.

Wealth, too, may affect the propensity of governments to manipulate the economy. Comparative studies suggest that economic manipulation is less prevalent in richer and more developed democracies where voters may be better informed and more likely to perceive and punish electorally motivated economic interventions (Alt and Lassen 2006; Shi and Svensson 2006). We take account of the possibility by controlling for per capita GDP (Log).

Inflation may also affect an incumbent's decision to manipulate the economy. Increased consumption spending further raises price levels, which may reduce the effectiveness of economic manipulation (Franzese 2002; Lewis-Beck and Stegmaier 2000). During periods of rising prices, therefore, incumbents may shy away from raising consumption spending at the expense of investment. To account for this possibility, we include a control variable for annual inflation, measured by the change in the consumer price index. 
Revenue may additionally affect economic manipulation. Revenue shocks, like other income shocks, tend to increase investment at a faster rate than consumption (Blanchard 2011). Government revenue includes income from taxes, bonds, and lending and excludes grants.

A significant debt burden can be an electoral liability. Voters disapprove of deficit spending and withdraw support from governments that accumulate debt (Brender and Drazen 2008). This may give more indebted governments enhanced incentives to improve their reelection chances by manipulating compositional spending. We therefore control for the gross Debt to GDP ratio.

Chief executives, who lead larger, more electorally dominant parties, face fewer constraints on their power in government, which may give them greater scope to manipulate the economy when fighting for reelection. We account for this possibility by including the vote share of the largest incumbent party.

In addition, the number of parties in government may affect economic manipulation. Bigger coalitions run larger public sectors and spend more because they strike less efficient policy bargains and externalize costs that are not immediately borne by their support coalitions (Bawn and Rosenbluth 2006). They also face difficult reelection challenges because coalition partners must differentiate themselves electorally from each other after having worked together in government. For both of these reasons more fractionalized coalitions may be more inclined to improve their reelection chances by manipulating the economy than smaller coalitions and single party governments. We control for government fractionalization, measured on a scale from zero to one, where zero indicates a single party government and one indicates a government in which every minister is a member of a different party. We employ multiple imputation to account for missing data, as recommended by Lall (2016), using Amelia II (Honaker, King, and Blackwell 2011).

\section{Estimation}

To test our hypotheses, we estimate the following equation:

$$
\begin{aligned}
& \text { Consumption to Investment } \\
& +\beta_{2, t} \text { Dissolution Powers }_{i, t}+\beta_{3} \text { Electoral Cycle }_{i, t} \\
& \left.\times \text { Dissolution Powers }_{i, t}\right)+\sum_{k=1}^{K} \gamma_{k} X_{k, i, t}+\eta_{t}+\varepsilon_{i, t},
\end{aligned}
$$

where $i$ indexes the country and $t$ indexes time. The dependent variable is fiscal policy manipulation, measured as the ratio of Consumption to Investment; Electoral Cycle $_{i, t}$ represents the proportion of the parliamentary term that has elapsed in country $i$ at time $t$. Dissolution Powers $s_{i, t}$ repre- sents the constitutional dissolution powers of the incumbent in country $i$ at time $t$. The term $X$ is a vector of $K$ control variables; $\eta_{t}$ represents time fixed effects, and $\varepsilon_{i, t}$ is the error term.

To capture the influence of temporal shocks, we include time fixed effects in our main model. In an alternative specification, we substitute a cubic polynomial time trend.

A further consideration is whether to include country fixed effects. Country fixed effects are attractive because they capture social, economic, and governance-related factors that may induce cross-national heterogeneity in the level of economic manipulation such as, for instance, social and party system fragmentation, the political leaning of governments, or the variety of capitalism that prevails in a country. An F-test suggests that country-level heterogeneity is a concern in these data. To the extent that we are interested in the effect of the elapsing electoral cycle on fiscal policy manipulation, which is time variant by definition, the inclusion of country fixed effects presents no difficulty. However, we are also interested in the effect of the incumbent's dissolution powers, which vary little within country over time in our sample. This makes the inclusion of country fixed effects theoretically inappropriate. To address this challenge, we proceed in two ways: first, in our main analysis, we present results with and without country fixed effects; second, we reestimate our main model taking account of a broad range of additional controls to capture potential sources of countrylevel heterogeneity, including legislative fragmentation, the prevalence of single party governments, the complexity of social cleavages, union density, the ideological orientation of governments, the age of democracy, European Union (EU) membership, fiscal decentralization, and trade openness, while omitting country fixed effects (analysis available in SI 3.3 and SI 3.4). Our results are robust to these alternative specifications.

Autocorrelation is an additional concern with time series data, and preliminary tests show that the level of manipulation in year $t$ is clearly correlated with manipulation in year $t-1$. Since we are interested in changes to the ratio over time, we include the lagged dependent variable, Consumption to Investment (lag), in our model. A Breusch-Godfrey test (Beck and Katz 1995; Keele and Kelly 2005) suggests that this strategy is effective in modeling autocorrelation in our data. We estimate all models with country clustered robust standard errors to account for within-unit correlation and heteroskedasticity.

\section{Results}

Table 1 presents the results. Model 1, our main model, includes year fixed effects. The alternative specification in 
Table 1. Dissolution Powers and Economic Manipulation over the Election Cycle

Dependent Variable: Consumption to Investment (Log)

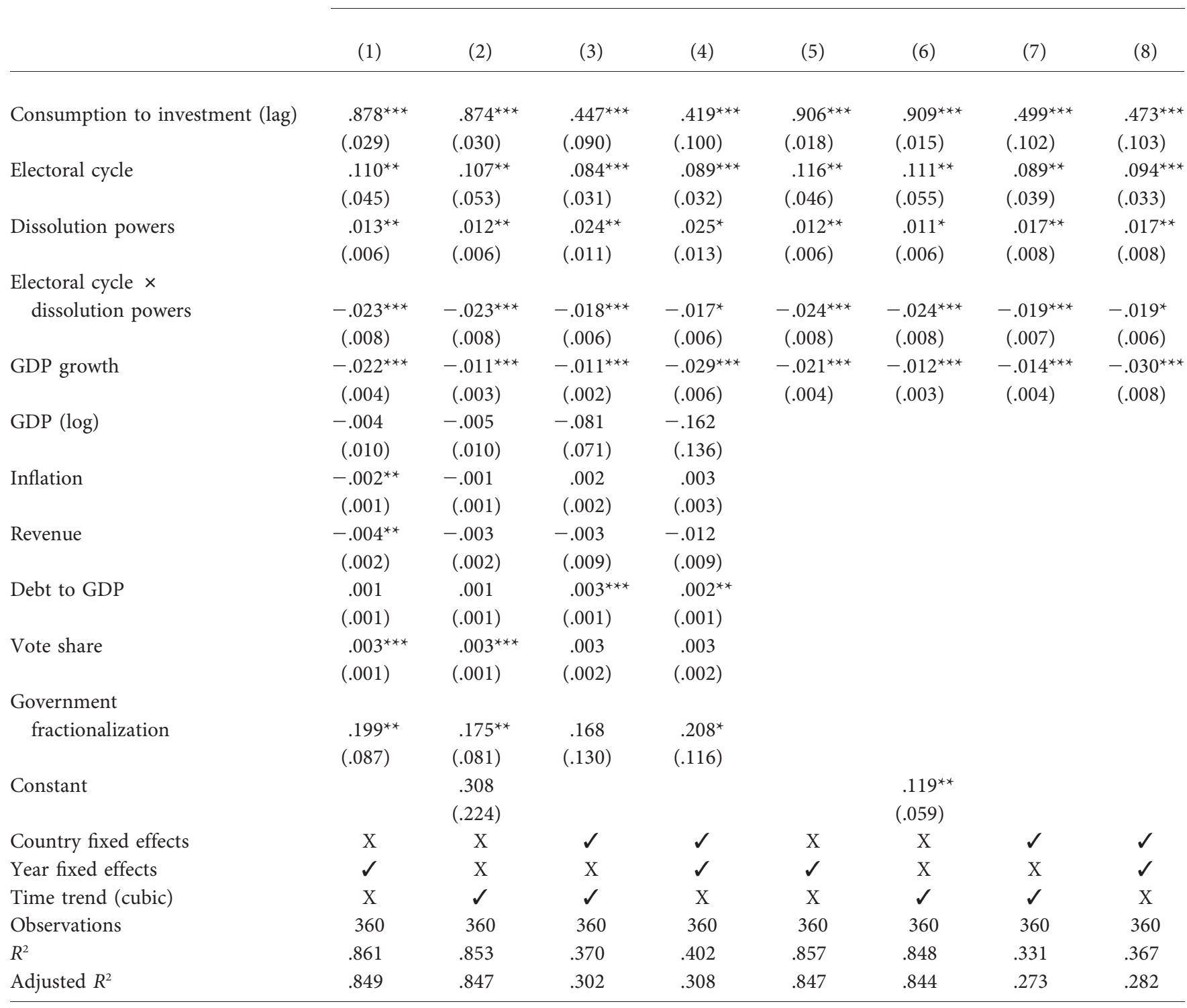

Note. Cluster robust standard errors in parentheses (clustered by country).

${ }^{*} p<.1$.

${ }^{* *} p<.05$.

$* * * 0.01$.

model 2 employs a cubic polynomial time trend in lieu of year fixed effects. Model 3 is estimated with country fixed effects and a cubic polynomial time trend. Model 4 employs country and year fixed effects. ${ }^{14}$ Models 5-8 are reduced forms of models 1-4.

14. Formally, we estimate country and year fixed effects models using the within-subject (within-year) estimator. Instead of including an intercept for each country (year), this estimator subtracts the country (year) mean
The results are substantively equivalent across all of these models. The coefficient of Electoral Cycle is always statistically significant and positive, which indicates that incumbents who lack assembly dissolution powers manipulate compositional spending. Over the course of the parliamentary

from each observation. Models using this estimator do therefore not estimate a constant. The within-subject estimator results in a smaller $R^{2}$ because it excludes between-subject variation that our models may explain. 
term, such incumbents raise the ratio of consumption spending to investment by $11 \%$ on average (cf. model 1 ). Moreover, the results make clear that incumbents substitute election timing for manipulation when that option is open to them: manipulation is muted when incumbents have assembly dissolution powers, as the negative interaction term Electoral Cycle $\times$ Dissolution Powers indicates.

Models 2-4 demonstrate that the results are robust to alternative specifications that employ various combinations of fixed effects and a time trend to account for potential cross-temporal and cross-national sources of heterogeneity. In all of these models only one control variable, GDP Growth, consistently reaches statistical significance and reduces economic manipulation, as anticipated. None of the remaining control variables have consistently statistically significant effects on economic manipulation across these four models. The reduced form models 5-8 show that the additional control variables have only a negligible impact on the relationship between the electoral cycle, dissolution powers and fiscal policy manipulation. The estimates of all variables of theoretical interest maintain similar magnitudes and statistical significance with or without these controls.

Since our hypotheses are tested using an interaction term, we illustrate the results with marginal effects plots. Recall the two competing hypotheses: hypothesis 1 states that incumbents complement preelection economic manipulation with opportunistic election timing when that power is available to them. Under this hypothesis, the effect of the elapsing electoral cycle on fiscal policy manipulation should not be conditional on the incumbent's dissolution powers. Hypothesis 2 states that incumbents substitute election timing for preelection economic manipulation when that option is open to them. That is, the elapsing electoral cycle should have the strongest effect on manipulation when incumbents have no discretion to dissolve parliament. This effect should weaken in the incumbent's dissolution powers, and governments with high levels of dissolution power should manipulate significantly less than their peers with little or no dissolution power. Moreover, according to hypothesis 2, an increase in the incumbent's dissolution powers should weaken manipulation. Thus, compared to their peers, incumbents with higher dissolution powers should keep the consumption to investment ratio lower at end of the electoral term and since they do not have to undo distortions after an election, they should also be able to keep the consumption to investment ratio higher at the beginning of the electoral term.

Figure 1 is based on our main model, model 1 (cf. table 1). Panel $A$ plots the marginal effect of the elapsing electoral term, varying the incumbent's dissolution powers, panel $B$ the marginal effect of dissolution powers, varying the pro- portion of the electoral term elapsed. Both panels reject hypothesis 1 and show that economic manipulation is conditional on the incumbent's assembly dissolution powers, as is consistent with hypothesis 2 .

Panel $A$ indicates that the marginal effect of the elapsing electoral cycle (i.e., an increase in the proportion of the term elapsed from 0 to 1 ) on manipulation is strongest when incumbents have no discretion to dissolve parliament (i.e., dissolution powers $=0$ ). Under those conditions, the elapsing of the whole electoral period is associated with an $11 \%$ increase in the consumption to investment ratio, as noted above. This effect weakens in the incumbent's discretion to dissolve parliament, and loses statistical significance when the government has a moderate level of power to influence early election calling (i.e., dissolution powers $=2$ ). When incumbents operate at high levels of dissolution power (i.e., dissolution powers $>=8$ ), the elapsing interelectoral term decreases manipulation, that is, over the course of the parliamentary term, these incumbents keep the ratio of consumption relative to investment significantly lower than their peers with less dissolution power, turning the ratio negative and significant. This pattern is consistent with the expectation generated by hypothesis 2: incumbents with extensive dissolution powers substitute election timing for economic manipulation so that they can afford to shift significantly less spending from consumption to investment over the electoral cycle than their peers with more limited dissolution powers.

Panel $B$ turns to the marginal effect of dissolution powers and shows that a one-step increase in dissolution powers (measured on a $0-10$ scale) weakens manipulation across the electoral cycle. That is, compared to their peers who manipulate the economy, incumbents with higher dissolution powers are, on average, able to maintain higher levels of investment spending late in the electoral cycle so that the ratio of consumption to investment spending turns negative and statistically significant at the end of the electoral term. Given that incumbents with higher dissolution powers do not divert investment spending into short-term consumption late in the interelectoral term, they are not compelled to reverse any manipulation early in the interelectoral term and can therefore keep consumption spending higher immediately after elections. Hence, as suggested by the marginal effect displayed in panel $B$, a rise in dissolution powers is associated with higher consumption spending for the first fifth of the parliamentary term and lower consumption spending during the final fifth of the term. This pattern provides further evidence for the substitution hypothesis (i.e., hypothesis 2), which suggests that increased dissolution powers reduce fiscal policy manipulation. 
A

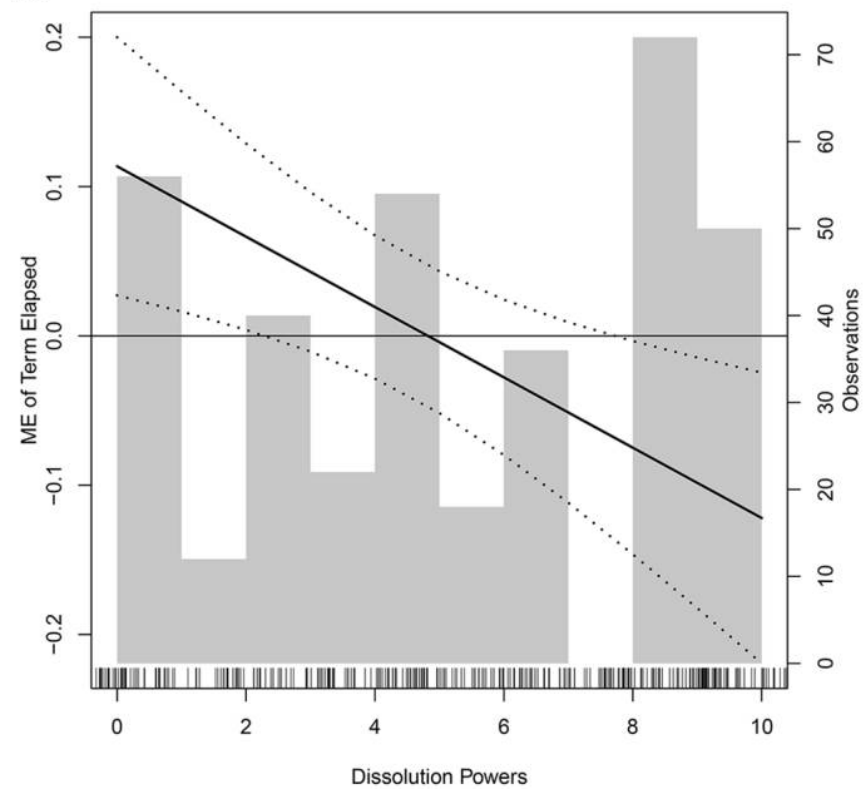

B

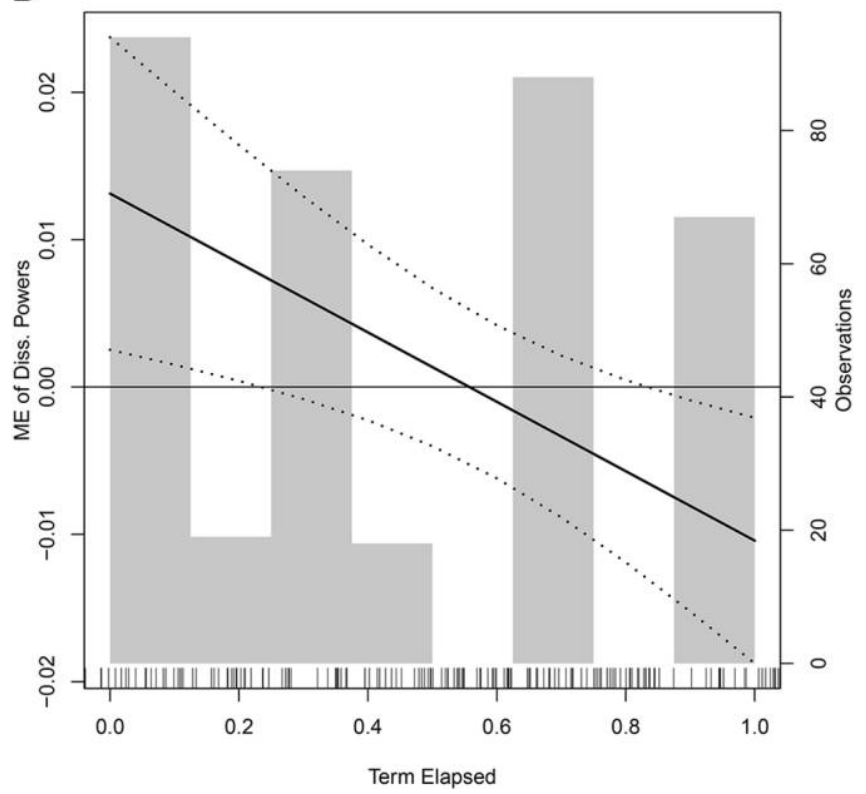

Figure 1. Panel $A$ plots the marginal effect of the elapsing electoral term, varying dissolution powers. Panel $B$ plots the marginal effect of dissolution powers, varying the proportion of the electoral term elapsed. Marginal effects are displayed with $95 \%$ confidence intervals. A rug plot depicting the frequency distribution of the observed values of each variable is superimposed.

The magnitude of the effects uncovered by this analysis is substantively meaningful. An $11 \%$ increase in the consumption to investment ratio is sizable compared to the effect of other important variables, such as annual GDP growth. Consider Spain, where incumbents have extensive discretion to dissolve parliament. In the period under observation, Spain's lowest annual level of GDP growth was - 3.75; its highest growth rate was 5.03. Increasing growth in Spain from its observed minimum to its maximum is associated with a sizable reduction in economic manipulation, that is, a decrease in the consumption to investment ratio of $18.98 \% .{ }^{15}$ If the incumbent had no discretion to time elections opportunistically, the economic manipulation engendered by approaching elections would do much to offset this effect.

As models 2-8 show, the results remain substantively unchanged across several alternative specifications. To further examine the robustness of our findings we perform an extensive range of additional analyses. First, we focus on alternative specifications of the dependent variable shedding light on the robustness of our results to the inclusion of transfers in compositional spending and on the difference between our approach and analyses of economic manipulation that do not employ compositional spending (SI 3.1). Second, we explore the stability of our results to alternative

15. Estimates are based on model 1 . ways of addressing change in our central explanatory variable (dissolution powers), examine the importance of dissolution powers as a mediator of politicians' choices to manipulate the economy, and probe the concern that dissolution powers may be adopted as part of a broader bundle of institutions, which may confound the relationship with economic manipulation (SI 3.2). Third, we examine the robustness of our results to potential social and political confounders that may simultaneously drive institutional choices (dissolution powers) and economic manipulation (SI 3.3). Fourth, we probe whether adding further controls for macropolitical and macroeconomic context (age of democracy, EU membership, fiscal decentralization, trade openness) alters the results (SI 3.4). These additional analyses suggest that our findings are robust. In sum, these results reject hypothesis 1 and simultaneously provide strong support for hypothesis 2 : governments with the ability to schedule opportunistic elections manipulate the economy less than their peers who lack this ability.

\section{CONCLUSION}

Our central finding is that politicians substitute opportunistically timed elections for distortionary economic manipulation. Incumbents who have the power to time elections opportunistically are less likely to manipulate the economy by diverting investment spending into short-term consumption in the run up to elections. In contrast, their peers who 
lack discretion to call elections raise the consumption to investment ratio as elections approach by up to $11 \%$.

The contributions of this finding are fourfold. First, it advances the unresolved theoretical debate in the political economy literature with broadly applicable insights into electoral politics and political business cycles across developed OECD democracies. We offer the first systematic crossnational comparative evidence to show that the constitutional power to engage in political surfing tempers electorally motivated economic interventions in mature parliamentary democracies. This result contributes to a better understanding of why economic policy cycles in developed democracies have proven so elusive in empirical work: the electoral cycle's effect on fiscal policy is conditioned by a government's discretion to time elections, which is prevalent in the constitutions of developed democracies. Electorally motivated economic manipulation, therefore, varies with the constitutional design of parliamentary democracies.

Second, our work is innovative in terms of research design and measurement. Ours is the first study to focus on the theoretically relevant strategic choice set available to politicians, that is, their constitutional power to schedule early elections in addition to manipulation, rather than actual election timing choices. This enables us to resolve the theoryempirics mismatch that has beset previous work on political budget cycles by capturing the choice that theoretical accounts focus on, namely, whether to manipulate the economy given that an incumbent does (or does not) have the option of influencing election timing. Moreover, the strategic choice set is constitutionally determined and therefore exogenous to incumbent competence and popularity, unlike actual election timing. This makes it possible to address the endogeneity bias that has beset previous work. Our study also innovates by demonstrating the importance of using a context-appropriate measure of economic manipulation. In high-transparency democracies incumbents have incentives to sidestep budget surveillance, debt ceilings, and reporting requirements. Shifts in compositional spending have precisely this property because they do not increase expenditure and budget deficits, while still enabling politicians to manipulate the economy for electoral gain.

Third, our findings have practical implications for current political reform debates about introducing or keeping fixed election dates in a range of countries, including the United Kingdom, Ireland, Australia, New Zealand, and Canada. One concern in these debates is that the introduction of fixed election dates may cause incumbents to replace opportunistic election timing with economic manipulation instead of enhancing accountability. Our study suggests that such concerns are valid and that institutional designers who wish to limit the scope for incumbent opportunism need to pay equal attention to the welfare implications of both strategies and give thought to ways of limiting their costs to society.

Finally, our study contributes to the comparative literature on the effects of political institutions. This literature counts dissolution powers among the most consequential institutional rules in parliamentary democracies. Yet, scholars working in this field have focused exclusively on the political effects of dissolution powers in areas including cabinet survival (Grofman and Van Roozendaal 1994; Schleiter and Morgan-Jones 2009; Strøm and Swindle 2002), the incumbent's reelection chances (Schleiter and Tavits 2016), and parliamentary bargaining (Becher and Christiansen 2015). Our results reveal that this institutional power also has an impact on the economy in that it tempers cyclical and self-interested interventions by incumbents in the economy for electoral gain. This finding contributes to a fuller appreciation of the practical consequences of dissolution powers and underlines the importance of these rules in affecting not just politics, but also the economy, in parliamentary democracies.

\section{ACKNOWLEDGMENTS}

We would like to thank Hanna Bäck, Johannes Lindvall, Richard Povey, and Jan Teorell for their very helpful advice and suggestions. We also thank the editor and our anonymous reviewers for their feedback. Previous versions of this manuscript were presented at seminars at the University of Lund, Australian National University, University of Essex, University College London, and the University of Oxford. We thank the participants for their suggestions and comments.

\section{REFERENCES}

Achen, Christopher H., and Larry M. Bartels. 2016. Democracy for Realists: Why Elections Do Not Produce Responsive Government. Princeton, NJ: Princeton University Press.

Aidt, Toke S., Francisco J. Veiga, and Linda G. Veiga. 2011. "Election Results and Opportunistic Policies: A New Test of the Rational Political Business Cycle Model.” Public Choice 148 (1): 21-44.

Alesina, Alberto, Gerald D. Cohen, and Nouriel Roubini. 1993. "Electoral Business Cycle in Industrial Democracies." European Journal of Political Economy 9 (1): 1-23.

Alt, James, and David Dreyer Lassen. 2006. "Transparency, Political Polarization, and Political Budget Cycles in OECD Countries." American Lournal of Political Science 50 (3): 530-50.

Alt, James, David Dreyer Lassen, and Joachim Wehner. 2014. “It Isn't Just about Greece: Domestic Politics, Transparency and Fiscal Gimmickry in Europe." British Journal of Political Science 44 (4): 707-16.

Andrews, Josephine T., and Robert W. Jackman. 2005. "Strategic Fools: Electoral Rule Choice under Extreme Uncertainty." Electoral Studies 24 (1): 65-84. 
Asdrubali, Pierfederico, Bent Sørensen, and Oved Yosha. 1996. "Channels of Interstate Risk Sharing: United States, 1963-1990.” Quarterly Journal of Economics 111 (4): 1081-110.

Barreiro, Belen. 2008. "Explaining the Electoral Performance of Incumbents in Democracies." In Jose Maria Maravall and Ignacio Sánchez-Cuenca, eds., Controlling Governments: Voters, Institutions, and Accountability, vol. 7. Cambridge: Cambridge University Press, 17-44.

Bawn, Kathleen, and Frances Rosenbluth. 2006. "Short versus Long Coalitions: Electoral Accountability and the Size of the Public Sector." American Journal of Political Science 50 (2): 251-65.

Becher, Micheal, and Flemming Juul Christiansen. 2015. "Dissolution Threats and Legislative Bargaining." American Journal of Political Science 59 (3): 641-55.

Beck, Nathaniel, and Jonathan N. Katz. 1995. "What To Do (and Not To Do) with Time-Series Cross-Section Data." American Political Science Review 89 (3): 634-47.

Blais, Andre, Donald Blake, and Stephane Dion. 1993. "Do Parties Make a Difference? Parties and the Size of Government in Liberal Democracies." American Journal of Political Science 37 (1): 40-62.

Blanchard, Olivier. 2011. Macroeconomics. 5th ed. Boston: Prentice Hall.

Brender, Adi, and Allan Drazen. 2005. "Political Budget Cycles in New versus Established Democracies." Lournal of Monetarv Economics 52 (7): 1271-95.

Brender, Adi, and Allan Drazen. 2008. "How Do Budget Deficits and Economic Growth Affect Reelection Prospects? Evidence from a Large Panel of Countries." American Economic Review 98 (5): 2203-20.

Canes-Wrone, Brandice, and Jee-Kwang Park. 2012. "Electoral Business Cycles in OECD Countries." American Political Science Review 106 (1): $103-22$.

Cargill, Thomas F., and Michael M. Hutchinson. 1991. "Political Business Cycles with Endogenous Election Timing: Evidence from Japan.” $\underline{R e-}$ view of Economics and Statistics 73 (4): 733-39.

Chappell, D., and D. A. Peel. 1979. "On the Political Theory of the Business Cycle." Economics Letters 2 (4): 327-32.

Chowdhury, Abdur R. 1993. "Political Surfing over Economic Waves: Parliamentary Election Timing in India." American Journal of Political Science 37 (4): 1100-1118.

Clark, William Roberts. 2003. Capitalism, Not Globalism: Capital Mobility, Central Bank Independence, and the Political Control of the Economy. Ann Arbor: University of Michigan Press.

Clark, William Roberts, Usha Nair Reichert, Sandra Lynn Lomas, and Kevin L. Parker. 1998. "International and Domestic Constraints on Political Business Cycles in OECD Economies." International Organization 52 (1): 87-120.

Cusack, Thomas. 2001. "Partisanship in the Setting and Coordination of Fiscal and Monetary Policies." European Journal of Political Research 40 (1): 93-115.

Drazen, Allan. 2001. "The Political Business Cycle after 25 Years.” NBER Macroeconomics Annual 15:75-117.

Duch, Raymond M., and Randolph T. Stevenson. 2008. The Economic Vote: How Political and Economic Institutions Condition Election Results. Cambridge: Cambridge University Press.

Efthyvoulou, Georgios. 2012. "Political Budget Cycles in the European Union and the Impact of Political Pressures." Public Choice 153 (3-4): 295-327.

Elster, Jon. 1995. "Forces and Mechanisms in the Constitution-Making Process." Duke Law Journal 45 (2): 364-96.

Fiorina, Morris P. 1981. Retrospective Voting in American Politics. New Haven, CT: Yale University Press.

Franzese, Robert J. 2002. Macroeconomic Policies of Developed Democracies. Cambridge: Cambridge University Press.
Franzese, Robert J. 2003. "Multiple Hands on the Wheel: Empirically Modeling Partial Delegation and Shared Policy Control in the Open and Institutionalized Economy." Political Analvsis 11 (4): 445-74.

Franzese, Robert J., and Karen Long Jusko. 2006. "Political-Economic Cycles." In Donald A. Wittman and Barry R. Weingast, eds., Oxford Handbook of Political Economy. Oxford: Oxford University Press, 545-64.

Frye, Timothy. 2010. Building States and Markets after Communism: The Perils of Polarized Democracy. Cambridge: Cambridge University Press.

Gelineau, F., and K. L. Remmer. 2006. "Political Decentralization and Electoral Accountability: The Argentine Experience, 1983-2001." British Journal of Political Science 36 (1): 133-57.

Goplerud, Max, and Petra Schleiter. 2016. "An Index of Assembly Dissolution Powers.” Comparative Political Studies 49 (4): 427-56.

Grofman, Bernard, and Peter Van Roozendaal. 1994. "Toward a Theoretical Explanation of Premature Cabinet Termination." European Journal of Political Research 26 (2): 155-70.

Hallerberg, Mark, Lucio Vinhas de Souza, and William Roberts Clark. 2002. "Political Business Cycles in EU Accession Countries." European Union Politics 3 (2): 231-50.

Hansen, Susan B. 1999. "'Life Is Not Fair': Governors' Job Performance Ratings and State Economies." Political Research Quarterly 52 (1): $167-88$.

Healy, Andrew, and Neil Malhotra. 2013. "Retrospective Voting Reconsidered." Annual Review of Political Science 16:285-306.

Heckelman, Jac C., and Hakan Berument. 1998. "Political Business Cycles and Endogenous Elections." Southern Economic Journal 64 (4): 987-1000.

Hepp, Ralf, and Jurgen von Hagen. 2012. "Interstate Risk Sharing in Germany: 1970-2006." Oxford Economic Papers 65 (1): 1-24.

Hibbs, Douglas A. 2006. "Voting and the Macroeconomy." In Barry R. Weingast and Donald A. Wittman, eds., The Oxford Handbook of Political Economy. Oxford: Oxford University Press, 565-86.

Honaker, James, Gary King, and Matthew Blackwell. 2011. "Amelia II: A Program for Missing Data." Journal of Statistical Software 45 (7): 1-47.

Ito, Takatoshi. 1990. "The Timing of Elections and Political Business Cycles in Japan." Journal of Asian Economics 1 (1): 135-56.

Ito, Takatoshi, and Jin Hyuk Park. 1988. "Political Business Cycles in the Parliamentary System.” Economics Letters 27 (3): 233-38.

Katsimi, Margarita, and Vassilis Sarantides. 2012. "Do Elections Affect the Composition of Fiscal Policy in Developed, Established Democracies?" Public Choice 151 (1): 325-62.

Kayser, Mark Andreas. 2005. "Who Surfs, Who Manipulates? The Determinants of Opportunistic Election Timing and Electorally Motivated Economic Intervention." American Political Science Review 99 (1): 17-27.

Kayser, Mark Andreas, and Michael Peress. 2012. "Benchmarking across Borders: Electoral Accountability and the Necessity of Comparison." American Political Science Review 106 (3): 661-84.

Keele, Luke, and Nathan J. Kelly. 2005. "Dynamic Models for Dynamic Theories: The Ins and Outs of Lagged Dependent Variables." Political Analysis 14 (2): 186-205.

Key, V. O. 1966. The Responsible Electorate. Cambridge, MA: Harvard University Press.

Lächler, Ulrich. 1982. "On Political Business Cycles with Endogenous Election Dates." Journal of Public Economics 17 (1): 111-17.

Lall, Ranjit. 2016. "How Multiple Imputation Makes a Difference." $P_{0-}$ litical Analysis 24 (4): 414-33.

Lewis-Beck, Michael, and Mary Stegmaier. 2000. "Economic Determinants of Electoral Outcomes." Annual Review of Political Science 3 (1): 183-219.

Nannestad, Peter, and Martin Paldam. 1994. "The VP-Function: A Survey of the Literature on Vote and Popularity Functions after 25 Years." Public Choice 79 (3): 213-45. 
New Zealand Parliamentary Service. 2013. "Parliamentary Terms: Fixed and Flexible." Parliamentary Library Research paper, New Zealand Parliament (March)

Nordhaus, William D. 1975. “The Political Business Cycle." Review of Economic Studies 42 (2): 169-90.

Powell, G. Bingham. 2000. Elections as Instruments of Democracy: Majoritarian and Proportional Visions. New Haven, CT: Yale University Press.

Powell, G. Bingham, and Guy D. Whitten. 1993. "A Cross-National Analysis of Economic Voting: Taking Account of the Political Context." American Journal of Political Science 37 (2): 391-414.

Rajan, Raghuram G., and Luigi Zingales. 1998. "Which Capitalism? Lessons from the East Asian Crisis." Journal of Applied Corporate Finance 11 (3): 40-48.

Rogoff, Kenneth. 1990. "Equilibrium Political Budget Cycles." American Economic Review 80 (1): 21-36.

Rogoff, Kenneth, and Anne Sibert. 1988. "Elections and Macroeconomic Policy Cycles." Review of Economic Studies 55 (1): 1-16.

Roy, Jason, and Christopher Alcantara. 2012. "The Election Timing Advantage: Empirical Fact or Fiction?” Electoral Studies 31 (4): 774-81.

Schleiter, Petra, and Sukriti Issar. Forthcoming. "The Heterogeneity of Early Elections."

Schleiter, Petra, and Edward Morgan-Jones. 2009. "Constitutional Power and Competing Risks: Monarchs, Presidents, Prime Ministers, and the Termination of East and West European Cabinets." American Political Science Review 103 (3): 496-512.
Schleiter, Petra, and Margit Tavits. 2016. "The Electoral Benefits of Opportunistic Election Timing." Lournal of Politics 78 (3): 836-50.

Schleiter, Petra, and Margit Tavits. 2018. "Voter Reactions to Incumbent Opportunism." Journal of Politics 80 (4): 1183-96.

Schneider, Christina J. 2010. "Fighting with One Hand Tied behind the Back: Political Budget Cycles in the West German States.” $\underline{\text { Public }}$ Choice 142 (1): 125-50

Shi, Min, and Jakob Svensson. 2003. "Political Budget Cycles: A Review of Recent Developments." Nordic Journal of Political Economy 29 (1): 67-76.

Shi, Min, and Jakob Svensson. 2006. "Political Budget Cycles: Do They Differ across Countries and Why?" Journal of Public Economics 90 (8): 1367-89.

Smith, Alastair. 2004. Election Timing. Cambridge: Cambridge University Press.

Strøm, Kaare, and Stephen M. Swindle. 2002. "Strategic Parliamentary Dissolution.” American Political Science Review 96 (3): 575-91.

Tufte, Edward. 1978. Political Control of the Economy. Princeton, NJ: Princeton University Press.

Vergne, Clemence. 2009. "Democracy, Elections and Allocation of Public Expenditures in Developing Countries." European Journal of Political Economy 25 (1): 63-77.

Voia, Marcel-Cristian, and J. Stephen Ferris. 2013. "Do Business Cycle Peaks Predict Election Calls in Canada?" European Journal of Political Economy 29 (March): 102-18.

Wolfers, Justin. 2007. “Are Voters Rational? Evidence from Gubernatorial Elections.” Working paper, University of Pennsylvania. 